\title{
Evaluation of Red Fleshed Guava (Psidium guajava L.) Varieties for their Processing Potential
}

\author{
G.K. Ravi ${ }^{*}$, Praveen Jholgiker ${ }^{2}$, K.S. Thippanna ${ }^{3}$, \\ B.N. Praveen Kumar ${ }^{4}$ and S. Pattepur ${ }^{5}$
}

${ }^{1}$ Department of Fruit Science, College of Horticulture, Bagalkot, University of Horticultural Sciences, Bagalkot, Karnataka, India

${ }^{2}$ Department of Fruit Science, ${ }^{3}$ Department of Post-harvest technology, ${ }^{4}$ Department of Soil Science and Agricultural chemistry, College of Horticulture, Bidar, Karnataka, India

${ }^{5}$ Department of Fruit Science, College of Horticulture, Bagalkot, Karnataka, India

*Corresponding author

\section{A B S T R A C T}

\begin{tabular}{|c|}
\hline Keywords \\
\hline $\begin{array}{l}\text { Guava, Microbial } \\
\text { load, Quality, RTS } \\
\text { and processing }\end{array}$ \\
\hline Article Info \\
\hline $\begin{array}{l}\text { Accepted: } \\
04 \text { October } 2018 \\
\text { Available Online: } \\
10 \text { November } 2018\end{array}$ \\
\hline
\end{tabular}

Five red fleshed guava varieties viz., Arka Kiran, Lalit, H-17-16, Punjab Pink and Arka Rashmi were evaluated for their processing potential. The processed products viz., squash, RTS and Jelly were prepared from these 5 varieties and assessed for their quality during storage. The squash prepared from fruits of Punjab Pink retained maximum ascorbic acid $(58.3 \mathrm{mg} / 100 \mathrm{~g})$ even after 90 days of storage (DAS). The RTS prepared from fruits of Arka Rashmi at 30 and 90 DAS retained maximum ascorbic acid (34.33 and 26.75 $\mathrm{mg} / 100 \mathrm{~g}$ ). The jelly prepared from fruits of Lalit had retained maximum ascorbic acid of 19.71 and $15.67 \mathrm{mg} / 100 \mathrm{~g}$ at 30 and $90 \mathrm{DAS}$. While the lycopene retention was maximum in squash, RTS and Jelly prepared from fruits of Arka Kiran. With respect to organoleptic evaluation the overall acceptability was found to be maximum in squash and RTS prepared from fruits of variety H-17-16, whereas for jelly prepared from fruits of Arka Rashmi. The minimum microbial load (cfu/ml) at 90 DAS was observed in squash prepared from fruits of Arka Kiran and Arka Rashmi, in RTS prepared from Lalit and Arka Rashmi and in Jelly prepared from Arka Rashmiand Lalit.

\section{Introduction}

Guava (Psidium guajava L.) belongs to the family Myrtaceae is one of the most delicious and popular fruit widely grown in tropical and sub-tropical region of the country (Chaitany et al., 1997). In India it is commonly known as "apple of tropics" and considered the fifth most important fruit in terms of area and production (Anon, 2017). It excels most of the other fruit crops in productivity, hardiness and adaptability. Nutritionally guava is a rich fruit containing high amounts of Vitamins A, B1 (Thiamine), B2 (Riboflavin) and C (70-350 $\mathrm{mg} / 100 \mathrm{~g}$ of pulp). The vitamin $\mathrm{C}$ content of guava fruit is $2-5$ times more than citrus 
(Singh, 2005). Apart from vitamin C, it is also a rich source of minerals like calcium, phosphorus, iron and pectin which ranges from 0.52 to $2.0 \%$. Therefore, it is an ideal fruit for the nutritional security. Guava fruit is normally consumed as fresh fruit due to excellent flavour, high digestive and nutritive value. High palatability and availability of guava fruits show great potential for processing into value added products, which have nutritional as well as health benefits. The fruit has a promising processing potential and used in making number of processed products such as nectar, squash, clarified juice, concentrates, canned, dehydrated powder, jam, jelly, RTS and blends with other juices. Processing of fruit into various products is one of the best ways to reduce post-harvest losses (Bons and Dhawan, 2013). The increase in demand for red pulp varieties off late is owing to the consumer preference for juices, jams and jellies with natural colours and awareness regarding antioxidant property of red pigmentation. Thus, keeping in mind all these prospective, the present study aimed to develop three sugar based products i.e. Squash, RTS and Jelly from five varieties viz., Arka Kiran, Lalit, H-17-16, Punjab Pink and Arka Rashmi and to evaluate their Physico-chemical and organoleptic evaluation.

\section{Materials and Methods}

Five red fleshed guava varieties viz., Arka Kiran, Lalit, H-17-16, Punjab Pink and Arka Rashmi were evaluated for quality and stability of processed products viz., squash, RTS and Jelly during 2017-2018. The experiment was conducted in the laboratories of the Department of fruit Science and Postharvest technology, College of Horticulture, Bidar. The fruits for the experiment were collected from the guava orchard of 3 years old. The fruits were carefully choosen in order to obtain the optimum mature stage. The fruits were thoroughly washed and used for preparation of processed products viz., squash, RTS and Jelly. The experiment was implemented with Randomized block design (RBD) with four replications.

\section{Preparation of guava squash}

For the preparation of squash a known quantity of sugar $(525 \mathrm{~g})$ was added to measured quantity of water and boiled it to dissolve the sugar. During heating $6 \mathrm{~g}$ of citric acid was added and the prepared syrup was strained through coarse muslin cloth and then required quantity of guava pulp (300 g) was added. The mixture used here is $25 \%$ Fruit pulp $+40-50 \%$ TSS $+0.3 \%$ citric acid. The procedure followed in preparation of guava squash was as per Srivastava and Kumar (1994).

\section{Preparation of guava RTS}

For the preparation of RTS (Ready to serve) beverage, known quantity of sugar (375 g) was added to measured quantity of water (2.31 litres) and boiled it to dissolve the sugar. During heating $8.4 \mathrm{~g}$ of citric acid was added and the prepared syrup was strained through coarse muslin cloth and then required quantity of guava pulp was added (300 g). The steps and procedure was followed suggested by Srivastava and Kumar, 1994.

\section{Preparation of guava Jelly}

Mature ripe fruits (500 g) were thoroughly washed and cut into pieces. Water $(725 \mathrm{ml})$ and citric acid ( $1.25 \mathrm{~g}$ ) was added to the guava slices and it was boiled for 30 minute and the extractant was strained to a clear semi solid liquid. For the preparation of guava jelly, required quantity of sugar was added in extracted semi solid liquid and cooked. During cooking required quantity of citric acid (1.25 g) was added. The end-point was judged by sheet method or by maintaining the Total 
soluble Solids to $65 \%$ or cooking up to $105^{\circ} \mathrm{C}$ temperature (Srivastava and Kumar, 1994).

The quality parameters like ascorbic acid content was estimated in Squash, jelly and RTS beverage by using 2, 6-dichlorophenol indophenol visual titration method at 30 and 90 days of storage and the values were expressed in $\mathrm{mg} / 100 \mathrm{~g}$ of pulp (Ranganna, 1986). The lycopene content was estimated by using petroleum ether, acetone and anhydrous sodium sulphate and the observations were recorded at $503 \mathrm{~nm}$ in Spectrophotometer at 30 and 90 days of storage and the values were expressed in $\mathrm{mg} / 100 \mathrm{~g}$ of pulp (Ranganna, 1986).

The organoleptic evaluation for the traits like colour and appearance, flavour, taste and overall acceptability of processed products were done in Squash, RTS and jelly at 30 and 90 days of storage by the panel of judges by scoring on the basis of 9-point Hedonic scale (Ranganna, 1986) as mentioned below. The microbial count in processed products (Squash, RTS and Jelly) prepared from different varieties was recorded at $90^{\text {th }}$ day of storage. The microbial analysis was done by employing dilution plate count method (Somasegaran and Hoben, 1985).

For enumeration of bacterial counts, a $10 \mathrm{ml}$ sample of Squash, Jelly and RTS was weighed aseptically and was diluted in $90 \mathrm{ml}$ sterile water and subsequent dilutions were prepared up to $10^{2}$ by transferring $1 \mathrm{ml}$ aliquot from $10^{-1}$ to $9 \mathrm{ml}$ water blank. The filtrate was serially diluted to $10^{-1}$ and $10^{-2}$ and was used for the enumerating population of bacteria, yeast and mould by inoculating on suitable medium in duplicate. The culture media used was Potato dextrose agar for yeast and mould and Nutrient Agar for bacteria respectively. Required dilution of $1 \mathrm{ml}$ was transferred to sterilized petri plates and $15-20 \mathrm{ml}$ of cultured media was poured to it. The plates were shaken in anticlockwise direction to attain uniform distribution of dilution to the culture media. The plates were then allowed to solidify the media and incubated for 2-3 days at $26 \pm 2^{\circ} \mathrm{C}$. The plates were then observed for development of bacteria, yeast and moulds. The results were expressed as total counts or colony forming units (cfu/ml of sample) which was determined by using the following formula:

$\mathrm{Cfu} / \mathrm{ml}=\frac{\text { no.of colonies } \times \text { dilution factor }}{\text { volume of culture plate }}$

\section{Results and Discussion}

Red fleshed guava varieties are gaining importance due to their demand in processing industry owing to natural pink to red pigmentation of pulp. Identified promising red pulp varieties with high yielding ability were evaluated for their processing potential. Three processed products viz., Squash, RTS and Jelly were prepared and stored under ambient conditions. The results on their quality during storage and consumer acceptability are discussed here under.

\section{Squash}

The data pertaining to qualitative and organoleptic scores recorded for squash is mentioned in Table 1. The interpretation of results revealed that there was non-significant difference observed among the varieties for ascorbic acid content at $30 \mathrm{DAS}$, however the squash prepared from fruits of Punjab Pink at 90 DAS retained maximum ascorbic acid $(58.33 \mathrm{mg} / 100 \mathrm{~g})$ which was statistically on par with Arka Rashmi $(57.50 \mathrm{mg} / 100 \mathrm{~g})$. The interpretation of results obtained for lycopene retention in squash revealed that there was a decrease in lycopene content in the product from 30 to 90 DAS irrespective of squash prepared from different red fleshed guava varieties. 


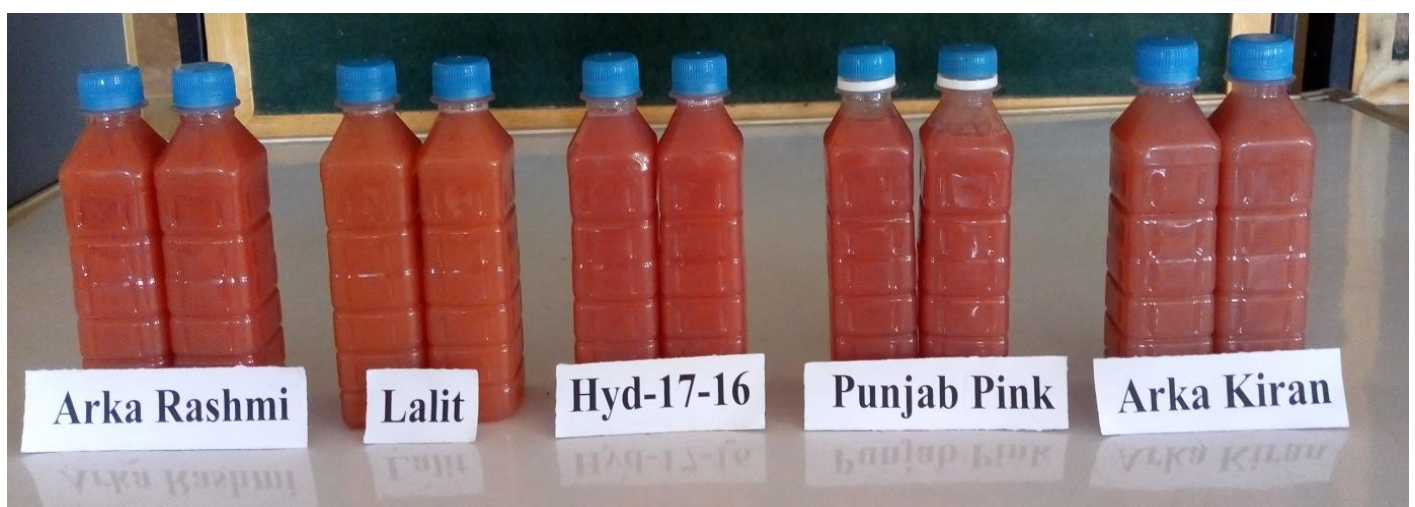

\section{Squash}

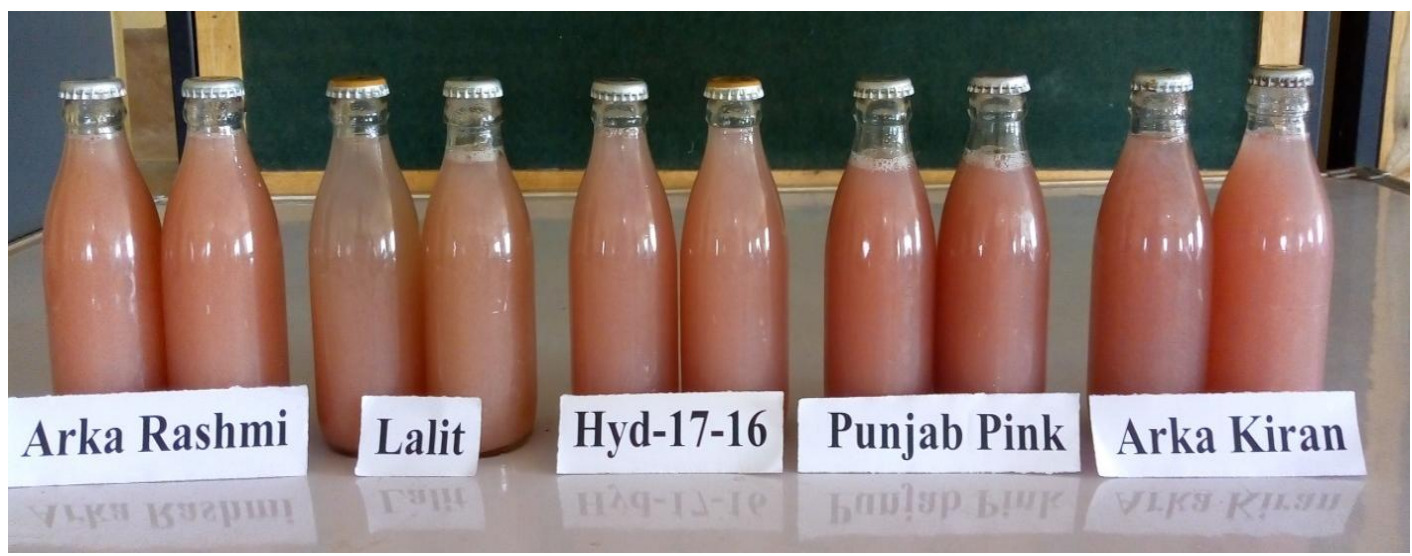

\section{RTS}

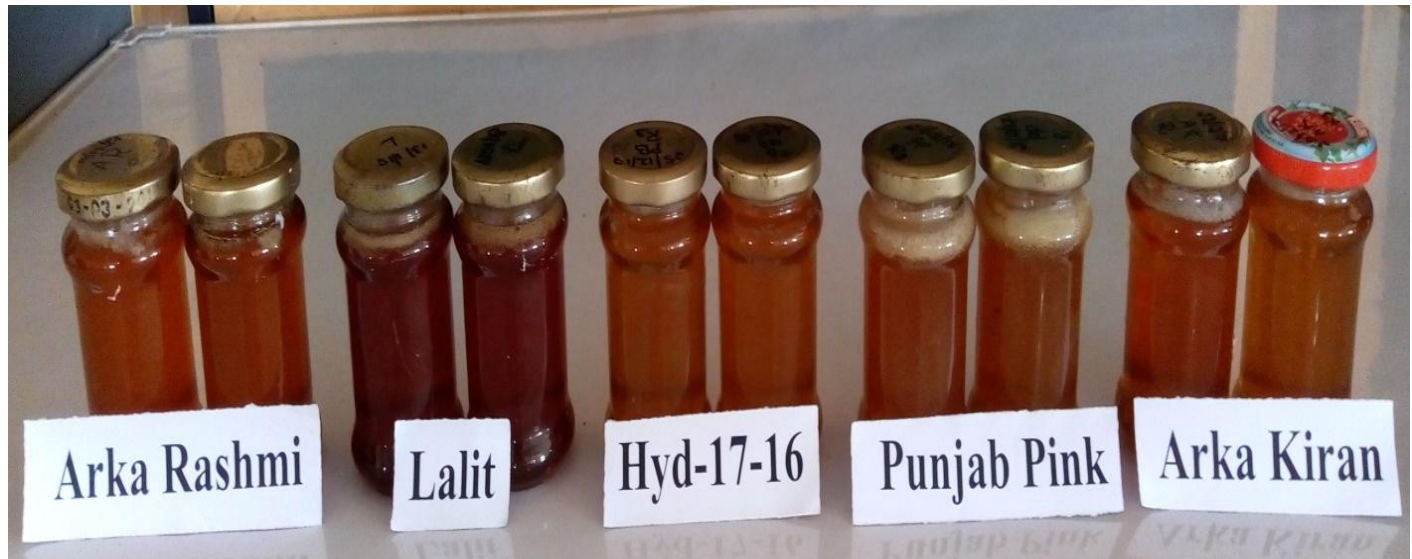

\section{Jelly}

Plate 1. Processed products of Squash, RTS and Jelly prepared from different red fleshed guava varieties 
Table.1 Qualitative assessment and organoleptic evaluation of squash prepared from different red fleshed guava varieties

\begin{tabular}{|c|c|c|c|c|c|c|c|c|c|c|c|c|c|c|}
\hline \multirow[t]{3}{*}{ Treatments } & \multirow{2}{*}{\multicolumn{2}{|c|}{$\begin{array}{c}\text { Ascorbic acid } \\
(\mathrm{mg} / 100 \mathrm{~g})\end{array}$}} & \multirow{2}{*}{\multicolumn{2}{|c|}{$\begin{array}{l}\text { Lycopene } \\
(\mathrm{mg} / 100 \mathrm{~g})\end{array}$}} & \multirow{2}{*}{\multicolumn{2}{|c|}{$\begin{array}{l}\text { Microbial count } \\
(\mathrm{cfu} / \mathrm{ml})\end{array}$}} & \multicolumn{8}{|c|}{ Organoleptic scoring } \\
\hline & & & & & & & \multicolumn{2}{|c|}{ Appearance } & \multicolumn{2}{|c|}{ Flavour } & \multicolumn{2}{|c|}{ Taste } & \multicolumn{2}{|c|}{$\begin{array}{c}\text { Overall } \\
\text { acceptability }\end{array}$} \\
\hline & $\begin{array}{c}30 \\
\text { DAS }\end{array}$ & $\begin{array}{c}90 \\
\text { DAS }\end{array}$ & $\begin{array}{c}30 \\
\text { DAS }\end{array}$ & $\begin{array}{c}90 \\
\text { DAS }\end{array}$ & $\begin{array}{l}\text { PDA } \\
\text { media }\end{array}$ & $\begin{array}{c}\text { NA } \\
\text { media }\end{array}$ & $\begin{array}{c}30 \\
\text { DAS }\end{array}$ & $\begin{array}{c}90 \\
\text { DAS }\end{array}$ & $\begin{array}{c}30 \\
\text { DAS }\end{array}$ & $\begin{array}{c}90 \\
\text { DAS }\end{array}$ & $\begin{array}{c}30 \\
\text { DAS }\end{array}$ & $\begin{array}{c}90 \\
\text { DAS }\end{array}$ & $\begin{array}{c}\text { 30 } \\
\text { DAS }\end{array}$ & $\begin{array}{c}90 \\
\text { DAS }\end{array}$ \\
\hline Arka Kiran & 56.73 & 39.84 & 1.76 & 1.25 & $0.72 \times 10^{2}$ & $\begin{array}{l}0.73 \\
\times 10^{2}\end{array}$ & 7.44 & 6.75 & 7.54 & 6.44 & 7.41 & 6.88 & 8.29 & 7.38 \\
\hline Lalit & 62.50 & 48.00 & 1.07 & 0.70 & $0.20 \times 10^{2}$ & $\begin{array}{l}6.00 \\
\times 10^{2}\end{array}$ & 6.78 & 5.95 & 7.31 & 6.50 & 6.95 & 6.24 & 7.16 & 6.26 \\
\hline H-17-16 & 58.66 & 48.00 & 1.64 & 1.25 & $6.67 \times 10^{2}$ & $\begin{array}{l}9.07 \\
\times 10^{2}\end{array}$ & 8.25 & 7.70 & 8.25 & 7.19 & 8.44 & 7.93 & 8.43 & 7.72 \\
\hline Punjab Pink & 69.23 & 58.33 & 1.59 & 1.21 & $1.20 \times 10^{2}$ & $\begin{array}{l}1.20 \\
\times 10^{2}\end{array}$ & 7.90 & 7.00 & 7.59 & 6.88 & 8.31 & 7.38 & 8.05 & 7.38 \\
\hline Arka Rashmi & 67.79 & 57.50 & 1.67 & 1.09 & $0.80 \times 10^{2}$ & $\begin{array}{l}0.66 \\
\times 10^{2}\end{array}$ & 8.13 & 7.07 & 8.09 & 7.19 & 8.14 & 7.24 & 8.11 & 7.69 \\
\hline S. Em \pm & 3.57 & 2.49 & 0.08 & 0.08 & & & 0.23 & 0.24 & 0.31 & 0.18 & 0.23 & 0.23 & 0.28 & 0.27 \\
\hline C.D.@ @ $5 \%$ & NS & 7.68 & 0.25 & 0.23 & & & 0.69 & 0.73 & NS & 0.55 & 0.70 & 0.72 & NS & 0.84 \\
\hline C. V. $(\%)$ & 11.33 & 9.90 & $\begin{array}{c}10.3 \\
8\end{array}$ & 13.70 & & & 5.83 & 6.91 & 8.09 & 5.20 & 5.78 & 6.55 & 6.97 & 7.50 \\
\hline
\end{tabular}

PDA - Potato dextrose agar

NA - Nutrient agar

DAS - Days after storage 
Table.2 Qualitative assessment and organoleptic evaluation of RTS prepared from different red fleshed guava varieties

\begin{tabular}{|c|c|c|c|c|c|c|c|c|c|c|c|c|c|c|}
\hline \multirow[t]{3}{*}{ Treatments } & \multirow{2}{*}{\multicolumn{2}{|c|}{$\begin{array}{l}\text { Ascorbic acid } \\
(\mathrm{mg} / 100 \mathrm{~g})\end{array}$}} & \multirow{2}{*}{\multicolumn{2}{|c|}{$\begin{array}{l}\text { Lycopene } \\
\text { (mg/100g) }\end{array}$}} & \multirow{2}{*}{\multicolumn{2}{|c|}{$\begin{array}{l}\text { Microbial count } \\
\quad(\mathrm{cfu} / \mathrm{ml})\end{array}$}} & \multicolumn{8}{|c|}{ Organoleptic scoring } \\
\hline & & & & & & & \multicolumn{2}{|c|}{ Appearance } & \multicolumn{2}{|c|}{ Flavour } & \multicolumn{2}{|c|}{ Taste } & \multicolumn{2}{|c|}{$\begin{array}{c}\text { Overall } \\
\text { acceptability }\end{array}$} \\
\hline & $\begin{array}{c}30 \\
\text { DAS }\end{array}$ & $\begin{array}{c}90 \\
\text { DAS }\end{array}$ & $\begin{array}{c}30 \\
\text { DAS }\end{array}$ & $\begin{array}{c}90 \\
\text { DAS }\end{array}$ & $\begin{array}{l}\text { PDA } \\
\text { media }\end{array}$ & $\begin{array}{c}\text { NA } \\
\text { media }\end{array}$ & $\begin{array}{c}30 \\
\text { DAS }\end{array}$ & $\begin{array}{c}90 \\
\text { DAS }\end{array}$ & $\begin{array}{c}30 \\
\text { DAS }\end{array}$ & $\begin{array}{c}90 \\
\text { DAS }\end{array}$ & $\begin{array}{c}30 \\
\text { DAS }\end{array}$ & $\begin{array}{c}90 \\
\text { DAS }\end{array}$ & $\begin{array}{c}\text { 30 } \\
\text { DAS }\end{array}$ & $\begin{array}{c}90 \\
\text { DAS }\end{array}$ \\
\hline Arka Kiran & 27.79 & 22.00 & 0.98 & 0.59 & $0.53 \times 10^{2}$ & $1.13 \times 10^{2}$ & 7.28 & 6.45 & 7.30 & 6.45 & 7.03 & 6.44 & 7.53 & 6.95 \\
\hline Lalit & 26.92 & 16.75 & 0.64 & 0.40 & $0.40 \times 10^{2}$ & $0.50 \times 10^{2}$ & 7.00 & 5.88 & 6.78 & 6.00 & 6.53 & 6.15 & 7.07 & 6.15 \\
\hline H-17-16 & 32.31 & 25.08 & 0.80 & 0.57 & $5.00 \times 10^{2}$ & $7.45 \times 10^{2}$ & 7.85 & 7.08 & 8.13 & 6.83 & 7.89 & 7.28 & 8.18 & 7.55 \\
\hline Punjab Pink & 31.16 & 24.58 & 0.68 & 0.46 & $0.47 \times 10^{2}$ & $4.60 \times 10^{2}$ & 7.58 & 6.08 & 7.02 & 6.41 & 8.20 & 7.28 & 7.90 & 6.92 \\
\hline Arka Rashmi & 34.33 & 26.75 & 0.85 & 0.60 & $0.40 \times 10^{2}$ & $0.47 \times 10^{2}$ & 7.63 & 6.35 & 7.60 & 6.75 & 7.61 & 6.74 & 7.55 & 7.25 \\
\hline S. Em \pm & 0.97 & 0.75 & 0.05 & 0.05 & & & 0.27 & 0.26 & 0.31 & 0.18 & 0.22 & 0.20 & 0.30 & 0.25 \\
\hline C.D.@ 5\% & 2.99 & 2.32 & 0.15 & NS & & & NS & NS & NS & 0.55 & 0.66 & 0.61 & NS & 0.79 \\
\hline C. V. $(\%)$ & 6.37 & 6.53 & $\begin{array}{c}12.2 \\
2\end{array}$ & 20.83 & & & 7.2 & 8.24 & 8.42 & 5.50 & 5.80 & 5.85 & 7.80 & 7.34 \\
\hline
\end{tabular}

PDA - Potato dextrose agar

NA - Nutrient agar

DAS - Days after storage 
Table.3 Qualitative assessment and organoleptic evaluation of Jelly prepared from different red fleshed guava varieties

\begin{tabular}{|c|c|c|c|c|c|c|c|c|c|c|c|c|c|c|}
\hline \multirow[t]{3}{*}{ Treatments } & \multirow{2}{*}{\multicolumn{2}{|c|}{$\begin{array}{l}\text { Ascorbic acid } \\
(\mathrm{mg} / 100 \mathrm{~g})\end{array}$}} & \multirow{2}{*}{\multicolumn{2}{|c|}{$\begin{array}{l}\text { Lycopene } \\
(\mathrm{mg} / 100 \mathrm{~g})\end{array}$}} & \multirow{2}{*}{\multicolumn{2}{|c|}{$\begin{array}{l}\text { Microbial count } \\
(\mathrm{cfu} / \mathrm{ml})\end{array}$}} & \multicolumn{8}{|c|}{ Organoleptic scoring } \\
\hline & & & & & & & \multicolumn{2}{|c|}{ Appearance } & \multicolumn{2}{|c|}{ Flavour } & \multicolumn{2}{|c|}{ Taste } & \multicolumn{2}{|c|}{$\begin{array}{c}\text { Overall } \\
\text { acceptability }\end{array}$} \\
\hline & $\begin{array}{c}30 \\
\text { DAS }\end{array}$ & $\begin{array}{c}90 \\
\text { DAS }\end{array}$ & $\begin{array}{c}\text { 30 } \\
\text { DAS }\end{array}$ & $\begin{array}{c}90 \\
\text { DAS }\end{array}$ & $\begin{array}{l}\text { PDA } \\
\text { media }\end{array}$ & $\begin{array}{l}\text { NA } \\
\text { media }\end{array}$ & $\begin{array}{c}\text { 30 } \\
\text { DAS }\end{array}$ & $\begin{array}{c}90 \\
\text { DAS }\end{array}$ & $\begin{array}{c}30 \\
\text { DAS }\end{array}$ & $\begin{array}{c}90 \\
\text { DAS }\end{array}$ & $\begin{array}{c}\text { 30 } \\
\text { DAS }\end{array}$ & $\begin{array}{c}90 \\
\text { DAS }\end{array}$ & $\begin{array}{c}30 \\
\text { DAS }\end{array}$ & $\begin{array}{c}90 \\
\text { DAS }\end{array}$ \\
\hline Arka Kiran & 16.73 & 11.33 & 1.43 & 0.97 & $1.40 \times 10^{2}$ & $5.47 \times 10^{2}$ & 8.00 & 7.31 & 7.75 & 7.13 & 7.81 & 7.06 & 8.25 & 7.50 \\
\hline Lalit & 19.71 & 15.67 & 1.08 & 0.75 & $0.80 \times 10^{2}$ & $0.87 \times 10^{2}$ & 8.50 & 7.81 & 7.50 & 6.81 & 8.00 & 7.13 & 8.00 & 7.38 \\
\hline H-17-16 & 15.38 & 10.50 & 1.05 & 0.86 & $6.0 \times 10^{2}$ & $0.53 \times 10^{2}$ & 7.75 & 7.06 & 7.75 & 7.06 & 7.38 & 6.69 & 7.25 & 6.25 \\
\hline Punjab Pink & 16.15 & 12.08 & 0.73 & 0.50 & $1.07 \times 10^{2}$ & $0.33 \times 10^{2}$ & 7.00 & 6.13 & 7.44 & 6.75 & 7.19 & 6.56 & 7.33 & 6.99 \\
\hline Arka Rashmi & 19.62 & 14.75 & 1.39 & 0.94 & $0.47 \times 10^{2}$ & $0.53 \times 10^{2}$ & 7.88 & 7.19 & 8.31 & 7.63 & 8.50 & 8.08 & 8.25 & 7.88 \\
\hline S. Em \pm & 1.09 & 0.94 & 0.09 & 0.08 & & & 0.31 & 0.19 & 0.27 & 0.28 & 0.26 & 0.27 & 0.27 & 0.40 \\
\hline C.D.@ 5\% & 3.35 & 2.90 & 0.27 & 0.24 & & & NS & 0.59 & NS & NS & 0.80 & 0.82 & 0.83 & NS \\
\hline C. V. $(\%)$ & 12.41 & 14.61 & $\begin{array}{c}15.1 \\
2\end{array}$ & 19.11 & & & 8.00 & 5.42 & 6.89 & 8.01 & 6.69 & 7.52 & 6.88 & 11.20 \\
\hline
\end{tabular}

PDA - Potato dextrose agar

DAS - Days after storage 


\begin{tabular}{|c|c|}
\hline \multicolumn{2}{|c|}{ Preparation of guava Jelly } \\
\hline Characteristics & Organoleptic score \\
\hline Like extremely & 9 \\
\hline Like very much & 8 \\
\hline Like moderately & 7 \\
\hline Like slightly & 6 \\
\hline Neither like nor dislike & 5 \\
\hline Dislike slightly & 4 \\
\hline Dislike moderately & 3 \\
\hline Dislike very much & 2 \\
\hline Dislike extremely & 1 \\
\hline
\end{tabular}

The maximum lycopene retention was recorded in Arka Kiran (1.76 and 1.25mg/100 g) at 30 and 90 DAS which was statistically on par with Arka Rashmi, Punjab Pink and H17-16 respectively. With respect to organoleptic evaluation high scores were registered for appearance, flavour, taste and overall acceptability for squash prepared from H-17-16.This may be attributed to good appearance and taste of products prepared from these varieties as the lycopene retention in the product was high and the nature of texture of pulp was soft with less or no grittiness resulting into formation of a clear juice with high acceptability. However the microbial load was high in the squash prepared from fruits of $\mathrm{H}-17-16\left(6.67 \times 10^{2}\right.$ and $9.07 \times 10^{2}$ for fungi and bacteria respectively) but was negligible in products prepared from Arka Rashmi and Arka Kiran. These results slightly differ with the findings of Kadam et al., 2012 who reported no fungal and bacterial infestation in freshly prepared squash.

\section{RTS}

The data pertaining to qualitative and organoleptic scores recorded for RTS is mentioned in Table 2. The findings pointed out maximum value of ascorbic acid content (34.33 and $26.75 \mathrm{mg} / 100 \mathrm{~g}$ ) in RTS prepared from fruits of Arka Rashmi which is statistically on par with H-17-16. High retention of lycopene $(0.85$ and 0.60 $\mathrm{mg} / 100 \mathrm{~g}$ ) was noted in RTS prepared from Arka Rashmi which was found on par with Arka Kiran and H-17-16. The organoleptic scores were recorded on 9 point hedonic scale. Non-significant differences were found for appearance and flavour, whereas high scores for taste and overall acceptability were obtained in RTS prepared from fruits of H-1716. This may be due to varietal character and good colour retention in processed product. The minimum microbial colonies $\left(0.40 \times 10^{2}\right.$ and $0.47 \times 10^{2}$ for fungi and bacteria respectively) were observed in Arka Rashmi. Similar findings were reported by Joshi et al., (2017) where highest organoleptic scores were obtained for pink-fleshed guava varieties.

\section{Jelly}

The data with respect to qualitative and organoleptic parameters in jelly prepared from five different red fleshed guava varietiesis presented in Table 3. The assessment of results clearly indicated that Jelly prepared from fruits of Arka Kiran and Arka Rashmi recorded maximum values for ascorbic acid and lycopene content at 30 DAS (16.73 and $19.62 \mathrm{mg} / 100 \mathrm{~g}$ ) and 90 DAS (11.33 and $14.75 \mathrm{mg} / 100 \mathrm{~g})$. Non-significant differences were noted for appearance and 
flavour whereas the parameter of taste and overall acceptability were high for jelly prepared from fruits of Arka Rashmi and Arka Kiran at both 30 and 90 DAS. The high scores for these varieties may be attributed to the good consistency and appearance of jelly, as these varieties are known to have high lycopene and pectin content (Dinesh and Vasugi, 2010). Further Paul et al., 2007 were also of the opinion that presence of high levels of pectin in fruits of guava cv. Khaja-4 and Khaja helped in retention of sensory quality of Jelly. With respect to microbial count the Jelly prepared from Arka Rashmi registered the low count for fungi $\left(0.47 \times 10^{2}\right)$ and bacteria $\left(0.53 \times 10^{2}\right)$. The overall assessment of squash, RTS and Jelly for quality during storage revealed that the variety Arka Rashmi was superior with respect to most of the quality parameters and with moderate organoleptic scores. Other varieties viz., H-17-16, Punjab Pink, and Arka Kiran were also found promising.

\section{References}

Anonymous, 2017. Department of Agriculture cooperation and farmer's welfare.http: //www.agricoop.nic.in.

Bons, H. K., and Dhawan, S. S. 2013. Studies on preservation of guava pulp. Indian J. Hort. 70(3): 452-454.

Chaitany, C. G., Kumar, G., Raina, B, L., and Muthoo, A. K. 1997. Effect of zinc and boron on shelf life of guava (Psidium guajava L.) cv. Sardar. J. Plant Sci. 10(2): 45-49.

Dinesh, M.R., and Vasugi, C. 2010. Phenotypic and genotypic variations in fruit characteristics of guava (Psidium guajava). Indian J. Agri. Sci. 80(11): 998-999.

Joshi, H., Kochhar, A., and Boora, R. S. 2017. Organoleptic and nutritional evaluation of value added products developed from new varieties of white and pink-fleshed guavas. Chem. Sci. Rev. Lett. 6(24): 2108-2113.

Kadam, D. M., Kaushik, P., and Kumar, R. 2012. Evaluation of guava products quality. Int. J. Food Sci. Nutr. Eng. 2(1): 7-11.

Paul, S. E., Chakrabarty, S., Jana, S. C., Hasan, M. A., and Mandal, K. K. 2007. A multivariate approach to study the sensory parameters of guava jelly on the basis of the physico-chemical parameters of guava fruit. Acta Hort. 735:561-568.

Ranganna, S., 1986. Handbook of analysis and quality control for fruit and vegetable products. Tata McGraw-Hill Education.

Singh, G., 2005. Strategies for improved production in guava. In: Kishun, R., Mishra, A.K., Singh, G. and Chandra, R. (Eds) Proc. $1^{\text {st }}$ Int. Guava Symp. CISH, Lucknow, India.

Somasegaran, P., and Hoben J. H. 1985. Methods in legume rhizobium technology. In: Handbook for Rhizobia. Springer-Verlag publishersNetherlands. pp. 450.

Srivastava, R. P., and Kumar, S. 1994.Fruit and Vegetable preservation: Principles and practices. CBS publishers and distributers Pvt. Ltd.

\section{How to cite this article:}

Ravi, G.K., Praveen Jholgiker, K.S. Thippanna, B.N. Praveen Kumar and Pattepur, S. 2018. Evaluation of Red Fleshed Guava (Psidium guajava L.) Varieties for their Processing Potential. Int.J.Curr.Microbiol.App.Sci. 7(11): 3475-3483. doi: https://doi.org/10.20546/ijcmas.2018.711.397 